\title{
The Examination of Private Shopping Clubs as A Virtual Retailer in the Frame of E- Commerce System.Case Analysis: Markafoni, Turkey
}

\author{
Müge ÖRS ${ }^{1, *}$, F. Özge BARUONU LATIF ${ }^{2}$ \\ ${ }^{1}$ Department of Business Management, University of Halic, Istanbul, Turkey \\ ${ }^{2}$ Department of Business Management, Doğuş University, Istanbul, Turkey \\ *Corresponding Author: mugeors@halic.edu.tr
}

Copyright (C) 2014 Horizon Research Publishing All rights reserved.

\begin{abstract}
Today rapidly evolving of Internet technologies enable the companies to carry their business activities to Internet. This situation provides firms to serve a wide range of customers and cost effectively. In the first part of this study, the definition of e- commerce, its pros and cons and classifications are examined briefly. Secondly, the concept of e-retailing and e-retailing business models are tried to be investigated in B2C business models. Afterwards private shopping clubs which are one of the famous virtual retailers are examined in the frame of e-retailing business models. Finally, Turkey's leading private shopping club, Markafoni and its business implications are included as a case study. An indepth interview is used as a qualitative research method with the Director of Brand Management of Markafoni
\end{abstract}

Keywords E-Commerce, E-Retailing, E-Retailing Business Models,Private Shopping Clubs

\section{The Concept of E-commerce and Its Pros\& Cons}

The Internet's evolution has been amazing. Nowadays, Internet is not only the primarily source of information, communication and entertainment, but also increasingly it is becoming a crucial vehicle for commercial activities. Yannopoulos [1] believes that e-commerce is a powerful tool that a business can use to gain a competitive advantage and it offers many opportunities for companies to grow in sales while reducing costs.

The use of the internet, by both individual consumers and business companies continues to be in progress. The development of internet technologies has brought crucial implications to both individual consumers and business companies. When consumers get benefit such as, richness of information, convenience of shopping, business organizations use internet as a tool for implementing cost-effective e-commerce directly [2].

When we look at the subject in terms of consumers, according to Quelch and Klein [3] e-commerce enables consumers to find product or services and get the price information quickly and having a search for a wide variety of sellers. So, the use of the Internet empowers customers today. Consumers have a chance to go on the Web and quickly find out where to get the lowest prices for a particular product or service. On the other hand, firms take advantages of the web technologies and establish e-commerce web sites to introduce products and distribute information. In addition to that, it is used for communication with customers and supporting them with a new technology [4] that enables companies to reach global countries and conduct business transaction with cost efficient- operations, depth product information and long-term customer satisfaction [5].

As it is seen that e-commerce has many advantages both to companies and consumers. Hence with the help of developing information technologies, e-commerce becomes an important issue with an increasing popularity in business day by day. According to the global e-commerce report of J.P Morgan e-commerce grows nearly $20 \%$ every year worldwide (J P Morgan,2013).

However if the concept of e-commerce which enables to firms a competitive advantage among their competitors is examined objectively, it is obviously seen that e-commerce has some disadvantages as well its positive sides. According to Avais and Samin [7] there are some advantages and disadvantages of e-commerce to companies are summarized below.

\subsection{Pros of E-commerce}

Boundary less (global location):In e- commerce transactions, there are no country boundaries. All companies can be active in global.

Time saving: In e- commerce transactions, there is no 
need to stand anywhere physically.This situation enables effective usage of time, capital and labor force.

No time constraints:E- commerce activities can be done in any time. This helps consumers a flexible shopping hours. There is no time constraint for companies and consumers in e- commerce activities.

Price/Product comparison:E- commerce activities aid consumers to compare price and products effectively and rapidly.

Cost effective:E-commerce transactions reduce most of cost problems such as logistics. Many of small and medium enterprises have a chance to compete with big companies in their field with the help of e- commerce activities.

Direct communication with consumer: Most of e-marketing techniques such as social networking sites, online advertising networks can be mediums to buzz about online store.

Improved customer interaction: Quick feedback and comment forms are main features to interact with customers.

Flexible target market segmentation: In e- commerce activities, marketers have the advantage of doing flexible target market segmentation and update it according to the feedbacks.

Simple and easier exchange of information: It improves information sharing among company and customers and it enables prompt quick just in time.

Easy arrangement of products: All products and the information of services can be arranged very quickly in online environment.

Faster buying procedure:In e- commerce activities there are no intermediates between company and consumers. So buying procedure is very fast and quick.

Easy transactions: In e- commerce, financial transactions are very fast and global. These transactions can be done from any country of the world in different amounts.

\section{2 .Cons of E-commerce}

Security:The issue of security challenges consumers especially in the process of payment.

Fake websites: Fake websites give a bad name to e-commerce process and confuses the consumer.

Fraud:Most of consumers are suspicious to do e-commerce transactions because of their financial and personal data are misused.

Fewer discounts and bargaining:The main disadvantage of e-commerce is lack of discount and bargaining chance for consumers.

Long and stressful delivery timing:Online products cannot be placed or touched. Consequently quality of the product is always a risk and delivery time of the online product is longer than a retail shop.

\section{The Classification of E-commerce}

Electronic commerce (e-commerce) is the changing way of business that influences the whole world. According to Chang and his friends [8] the rapidly change of computer technology provides e-commerce to allow companies to lead their business process, enhance customer service and offer new channel to customer. Chen and his colleagues [9] add to this concept that e-commerce is not just about buying and selling product or services but also includes specific information for customer that help them to find out the necessary production information, price comparison easily. Hence, e-commerce has directly impact on business owners, suppliers, and customers. On that point, e-commerce can be broken into four main categories: B2B, B2C, C2B, and C2C [9].

Vaithianathan [10] defines Business to Businesses (B2B) commerce as a market transaction in which businesses, governments, and other organizations depend on computer communications to make business transactions. Jennex, Amoroso and Adelakun [11] defined this concept as the exchange of products or services between businesses rather than businesses to consumers electronically. For instance these transactions may be conducted between a business and its supply chain members. Business to Customer (B2C) refers to e-commerce transaction of electronic sale of goods, services from businesses to individual consumers, such as alibaba.com, amazon.com, ebay.com. Consumer to Business (C2B) includes individual consumers who use the Internet to sell services or products to the companies or individuals who is looking for sellers to bid on products. Customer to Customer $(\mathrm{C} 2 \mathrm{C})$ e-commerce is a consumer transacts that are directly related with other consumers. $\mathrm{C} 2 \mathrm{C}$ e-commerce usually refers to the business model that focuses on individual trade or barter of goods with another individual. For example, selling phones or cars by individual consumers via internet could be an example for this subject.

\section{The Concept of E-Retailing in B2C}

Harris and Dennis [12] defined B2C e-retailing as the sales of goods and services via Internet for personal or household use by consumers. This definition covers all e-commerce activities that result in transactions with end consumers. It doesn't include business customers. On the other hand, some e-marketing like promoting brands or making advertising via internet to reach consumers can be considered to be part of $\mathrm{B} 2 \mathrm{C}$. However, they are not normally included as being within the scope of e-retailing [13].

E-retailers are generally classified as store based and non store based criteria. Initially, the e-retail business models are categorized by distribution channel which highlights how the customers can access the retailer's merchandise activities. According to this classification, Dennis and his colleagues [13] classify e-retailers as Click and mortar companies, direct retailers and virtual companies (click only companies).

Click and mortar companies are traditional brick and 
mortar companies that have added online marketing options to their business operations. Today to build a profitable business depends on integrating online and offline retailing activities together. Researches show that most of click and mortar companies are more successful than their virtual retailer competitors [14]. Direct retailers are the oldest form of retailers which built up a face to face relationship with customers using a catalogue system and door-to door selling. Avon is the most known one of direct retailers who uses this system since 1800's [15]. Kotler and Armstrong [16] identify virtual retailers as click only companies or pure-play e-retailers, serves customers via Internet. Virtual retailers do not have any physical stores. These retailers serve in a wide range of business. These are e-tailors such as Amazon who sell products and services directly to end users. There are also some transaction sites such as E-bay, content sites with subscription like Financial Times and search engines such as Yahoo or Google.

\subsection{E- retailing in Turkey}

Deloitte's European e-Retailing Index Report [17] reveals that European e- commerce market is developing rapidly. As a result of this growth, the European e-commerce market size exceeded U.S. e-commerce market size on the basis of total sales. As market is maturing quickly, international e-retailers focused on European local markets. Today, both pure-play retailers and traditional retailers (brick and mortar companies) are tuning to e- commerce technologies in local and global.

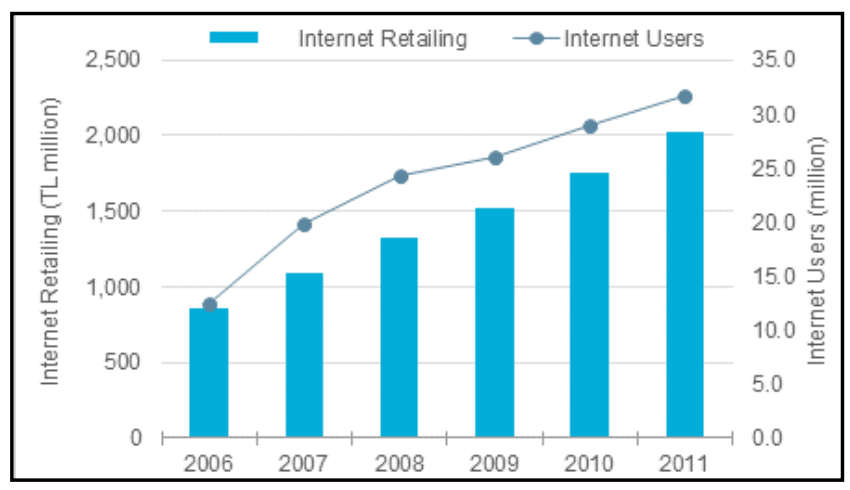

"nearly $1 €=2.8 \mathrm{TL}$

Figure 1. Turkey's Internet Users and Internet Retailing Value: 2006-2011

As the Figure 1 shows, Turkey's e-commerce volume constitutes a considerable place in this magnificent growth. Total numbers of internet users were 35 million in 2011. It means $48 \%$ of the total population. Turkey is ranked 4 th use of internet in the Europe and 12th use of internet in the world [18]. Turkey has a big advantage with its young population compared to many European country such as UK, Greece, Spain and USA [19].

Turkey has a positive progress in e- commerce as a result of a large young population familiar with new technology and solid economic growth, with real internet retailing value expanding by $61.1 \%$ over $2006-2011$.

In the line of these numbers, e-commerce applications in Turkey show a great movement from year to year. According to the total number and amount of e-commerce transaction with credit cards report by BKM (Banks Credit Card Center), it is seen that all e-commerce transactions have been increasing rapidly from 2005 to 2011 in Table 1. [20].

The rise of the volume of e-commerce transactions means also increasing in internet retailing ratios. According to the results of 2012 Internet technologies Household Survey of TUİK (Turkey's Statistics Agency), every one of the five people using internet is shopping on the internet. Individuals using rate of ordering/purchasing products or services for private use is $21,8 \%$ in 2012 . (This rate was $18,6 \%$ in 2011). In addition to that, the period covering 12 months from April 2011 to March 2012, 44\% of individuals purchased clothing and sports equipment, 25,5\% of individuals purchased electronic devices, $21,2 \%$ of individuals purchased home furniture, $18,3 \%$ of individuals food stuff and daily requirements, $17,4 \%$ of individuals purchased traveling requirements (tickets, booking, rent a car..etc.), $15,6 \%$ of individuals purchased book, magazine..etc.via internet [21].

E-retailing also emerges with a different type of business models in Turkey. These are brokerage firms, retailing-merchandising firms and direct selling firms. Online Retailing-merchandising firms can differ in various structures. There are some firms which enable a virtual market place for consumers such as hepsiburada.com, hizlial.com; firms which provide niche services such as çiçeksepeti.com, frutation.com; click and bricks as vatan.com.tr, teknosa.com.tr, kangurum.com, opportunity sites as sehirfirsatı.com, firsatciyız.com and private shopping clubs such as Markafoni.com, Limango.com, Trendyol.com [22].

Table 1. Total Number and amount of e-commerce transactions with credit cards in Turkey- BKM

\begin{tabular}{|c|c|c|c|c|c|}
\hline & 2008 & 2009 & 2010 & 2011 & 2012 \\
\hline $\begin{array}{c}\text { Number of } \\
\text { Transaction }\end{array}$ & 61.006 .068 & 67.311 .588 & 96.138 .157 & 134.770 .073 & 138.917 .871 \\
\hline $\begin{array}{c}\text { Amount of } \\
\text { Transaction } \\
\text { (million TL) }\end{array}$ & 8.000 & 8.926 & 14.123 & 22.118 & 24.596 \\
\hline
\end{tabular}

* nearly $1 €=2.8 \mathrm{TL}$ 
According to Deloitte's report (2012), e-commerce firms of Turkey are mostly click only companies. Turkey is the leading European country which has the highest rate of click only companies in e-commerce sales channel. $60 \%$ of the top 25 online retailers in Turkey use only e-commerce sales channel. When European markets are examined, it is seen that the click-only market players in Turkey, Netherlands and Sweden are better than bricks and mortar retailer in their country in the services of product search, payment options, customer-focused advices, social media integration and mobile commerce. Especially in Turkey click only market players such as Gittigidiyor.com, Markafoni. com, Trendyol.com received capital support for investment from eBay, Amazon.com, and Tiger Global firms. The year of 2011 has been very successful for Turkey in e-commerce investments. Turkish market, with its sustained growth, once again served as an attractive destination for investors. Deloitte's Annual Turkish Mergers\& Acquisition Review 2011 Report shows that there had been 12 deals in the value of 308 million USD in 2011 in e- commerce business area. These deals are listed in Table 2[23].

Table 2. Merger\& Acquisition Review of Turkey in e-commerce market, 2011

\begin{tabular}{|c|c|c|c|}
\hline Acquirer & Origin & Target & Stake \\
\hline ePlanet Capital & USA & Vipdukkan.com & $28.2 \%$ \\
\hline $\begin{array}{c}\text { Hummingbird } \\
\text { Ventures }\end{array}$ & Belgium & Ciceksepeti.com & ND \\
\hline Intel Capital & USA & Grupanya.com & ND \\
\hline iLab Ventures & Turkey & Unnado.com & $33.0 \%$ \\
\hline iLab Ventures & Turkey & Cimri.com & $100 \%$ \\
\hline $\begin{array}{c}\text { Tiger Global } \\
\text { Management }\end{array}$ & USA & trendyol.com & $20.1 \%$ \\
\hline $\begin{array}{c}\text { Tiger Global } \\
\text { Management } \\
\text { Kleiner Perkins } \\
\text { Caufield\& Byers }\end{array}$ & USA & trendyol.com & $21.7 \%$ \\
\hline
\end{tabular}

\section{Private Shopping Clubs as a E-Retailing Model}

Private shopping clubs as an e-retailing model are closed systems that sell limited number of certain brands ( Product groups could be from clothing, home furniture, personal care, restaurant, airplane, travel services etc...) online at discounts of up to $90 \%$. System is a closed system based on membership. Customers can have an opportunity to get product information and making purchases with the condition of becoming member of the website. The products that are exhibited in the web site are brands that made a deal previously. The number and variety of products are generally decided by suppliers. Price is formed by adding the profit margin of the private shopping club with the condition to be lower than the market value. Private shopping clubs are usually organizing sales events between 2 to 6 days.
According to Marcus [24] generally there are two different business approaches of private shopping clubs. These are "Block, Sell and Ship" model and "Buy and Distribute Direct" model. Most of sites operate on Block, sell and ship model. In first model, brands send some of samples of their products to private shopping site. The buyers then place their orders for the amount of merchandise they'd like the brands to set aside for the sale, based on available stock. After members pay for their goods, the sale ends. Private shopping clubs then places the confirmed purchase order with the brand for what it has sold online. Merchandise is then shipped to private shopping club. All orders are packaged in Private shopping club warehouses with its branded boxes and then shipped out to customers. This model includes few risks for private shopping clubs. Private shopping clubs have a right to worry about passing time between customer order and product delivery. Another risk of this model is related with the inventory of brands. Because if the balance of inventory could not be provided, most of customers start to ask about refunds that their order could not be filled. This situation creates customer dissatisfaction as well. Second model is "Buy and Distribute Direct" model. In this model private shopping site operates all activities (purchasing and fulfilling orders) directly by itself. It is risky comparing to Block, Sell and Ship model. The risky side of this model can be experienced in the absence of demand for products. However this model enables private shopping sites to give the best price and discounts to its members.

Private Shopping clubs are widespread around the world. The pioneer of this e-business model in Europe is a French company which is called Vente-Privee. VentePrivee is the founder of online sales event concept which is called flash sales also, firstly in world. Vente-privee.com is specializing in selling brand overstock since 2001; online sales are exclusive to its 15 million members in Europe. Registration to the vente-privee.com club is free and with no purchase obligation. Sales are for a limited time only ( 3 to 5 days) and organized with over 1,500 main international brands in all product categories. These categories are clothing, fashion accessories and the products of home, toys, sports equipment, high-tech and gastronomy. With 1,500 employees in 8 European countries, vente-privee.com generated 1.073 billion Euros (900 million pounds) in gross turnover in 2011, an $11 \%$ increase from 2010 [25].

The most popular American private shopping club is Gilt Group. It has nearly two million members. By the end of 2012, the company's sales will hit \$1bn in annual [26].

So, what are the key success factors of private shopping clubs? These can be listed as follows:

Key Features

- Exclusivity - Customer must be a member of group by herself or she must be invited by her friends to get in the system.

- Famous Brands - Customers have a chance to find quality products

- High Discounts - The main impulsive factor is price and high discounts on qualified and branded 
products

- Limited Time Events - limited sales event at which the merchandise is offered until it sells out or a time limit is reached

- Regular Events - Most of sales events start at the same time and these events becomes a daily routine for customers as doing a breakfast in the morning.

- Viral Invitations - member get member referral program (\$10 reward per new (purchasing) member

- Social Network Integration- Private shopping clubs have a wide range of social network Integration such as Facebook and Twitter. These networks enable customers to easy login and member referrals.

- Single/No Shipping Fee - Generally most of private shopping clubs do not get shipping fees from their customers [27].

In Turkey there are many private shopping clubs which have been in online business area since 2008. In terms of customer numbers and establishment years, Turkey's first three biggest private shopping sites are respectively Markafoni, Limango and Trendyol. If we have a brief summary about brands, these are listed as follows.

Limango was founded in Germany in 2007 with the initiative of three people and it is purchased by Otto Group in 2009 which is Germany's largest retail establishment. One of the most important growth plans in this purchasing process is establishing Limango in Turkey. Limango in Turkey started to operate at the end of April of 2009. Web site system operates for members or people who can be invited by a member as a friend. Limited numbers of well-known brands are delivered to the end user up to $70 \%$ discounts on site. The most important characteristic of site is giving momentary vouchers to its members. Another interesting implication is a member who gains a new member to a system as her/his friend, gets $10 \mathrm{TL}$ gift vouchers.

Limango has approximately 5 billion members. It has 15 billion web visit per month and over 150 billion web site seeing. Visitors spend averagely $8-10$ minutes in web site. Members structure is consist of $65 \%$ of women and $35 \%$ of men. The half of the ages between $25-45$ is the university graduates [28].

Another private shopping club is Trendyol. Trendyol.com was established in March 2010 with the aim of making accessible the most popular brands and designers to everyone. With more than 4 million members by the end of 2011, the company has been serving to its customers with a team of 600 employees and more than 1000 brands alternatives. The most important feature differentiates Trendyol from its competitors is presenting Turkish designers products for sale online firstly with the aim of supporting the Turkish designers [29]. One of the other successes of Trendyol's web site is not being just sales oriented. Website is serving as a platform for its members to follow the fashion with its blogs and social media channels. Trendyol is a multipartner company. The partners of the company are DemetMutlu (founder) and Tiger Group and Kleiner Perkins Caufield\& Byers. Trendyol which gets an investment of \$ 50 million in the last two years grew $300 \%$ in 2011 [30].

\section{Case Analysis: Leading Private Shopping Club of Turkey, Markafoni}

Introducing the private shopping concept to Turkey in 2008, Markafoni offers products from various categories, such as clothing, shoes, cosmetics, accessories, sports equipment, toys, technology and decoration of worldwide renowned prominent fashion brands with discounts reaching up to $90 \%$. Admitting members by means of invitations, the site intends to cherish a private shopping experience to its members by opening online boutiques of the fashion brands for 2-5 day periods by virtue of the organized campaigns.

Being Turkey's very first and leading private shopping club, Markafoni is not only active in Turkey, but also provides private shopping club services in Australia, Ukraine and Greece. $70 \%$ of the shares held by MIH-Allegro, which is affiliated to Naspers, a worldwide known multimedia giant active in 129 countries,Markafoni is taking rapid steps towards becoming a global brand[31].

Adopting the motto "every shopping is falling in love" for its business, Markafoni maintains its leader leading position amongst other private shopping clubs since 2008, its year of incorporation, by virtue of the diversity of offered product, special advantages, campaigns, reliability, convenience in return processes, quality of service, sponsorships and brand awareness.

Significant awards are conspicuous when the steps of achievement for Markafoni are observed. Markafoni was deemed worthy of and awarded with the Digital Enterprise of the Year award at Digital Age Awards organized by Digital Age periodical in year 2010, an awarded at the national virtue category in the 1st Golden Cart E-commerce Awards in year 2011. Ranked first at the «Best Web Enterprise» and the «Best Private Shopping Site» categories at Webrazzi 2011, Markafoni is elected as 2011 digital love mark of Turkey in private shopping category during the research conducted by Digital Age Periodical.

Markafoni has been the most admirable company of e-commerce sector in the research conducted by Capital Periodical in year 2012. The list of most brilliant 10 e-commerce sites in Turkey published in Wired, renowned technology and business periodical, contains markafoni.com, Turkey's first and leading private shopping club; as well as enmoda.com, Turkey's online fashion center, and zizigo.com, Turkey's largest online shoe shop, which are the affiliates of Markafoni. Moreover, Markafoni is elected to Turkey's 2012 List of Super Brands and is one of the five e-commerce brands and the sole private shopping club in the list.

\subsection{Markafoni with Numerical Data}

Markafoni, Turkey's first and leading private shopping 
club, maintains its leading position amongst other private shopping clubs. According to the Google Analytics data, Markafoni is visited 22 million times on monthly basis and the total number of individual visitors of Markafoni is reported to be 10 million individuals. More than 500 campaigns are organized in Markafoni on monthly basis and 700 thousand products are sold on average. The number of campaigns organized on the site in a single day, on the other hand, is around 20. With 6 million registered members, Markafoni stocks 2 million products in its logistics hub established on overall 25 thousand square meter area and realize sales of 700 thousand products on monthly basis with 70 thousand package shipment capacity. The "Studio City" within the administrative center building of Markafoni, established on 10 thousand square meter area, holds 14 photograph studios and Markafoni executes its operations currently in collaboration with 1.200 fashion brands.

75 percent of the Markafoni members are the female members and the remaining 25 percent are the male members. Considering the products and product diversities sold; 35 percent of the sold products are from women and children category (predominantly the garment and upper group sales), 25 percent from shoes and bags category ( 80 percent of which are sold to women), 24 percent from life style products (predominantly home textile products), 10 percent from men's products (predominantly t- shirt and shirts) and 6 percent from cosmetic products.

Markafoni receives orders from almost all provinces of Turkey, particularly from İstanbul as well as Ankara, Izmir, Bursa and Kocaeli.

\subsection{Brand Positioning}

Markafoni, Turkey's first and leading private shopping club, realizes the logistics operations within its own structure. Since December 2010, Markafoni perpetuates its business activities from the logistics hub established on 25 thousand square meter area, which represents the largest logistics hub of the Turkish internet world. The primary field of activity of the logistics hub is to perform quality control operations of approximately 150 thousand products received from approximately 50 different suppliers on daily basis, to allocate the products according to the customer orders and to assure forwarding of the ordered products to Markafoni members within stipulated duration. Daily shipment capacity of Markafoni logistics hub is 70 thousand packages, while product storage capacity is 2 million products.

Offering VIP services to the customers is a significant feature of Markafoni, which differentiate the brand from its rivals with respect to customer satisfaction. The members of Markafoni can reach the customer services and be informed on $7 / 24$ basis both via telephone and also as online. Being the first private shopping club of Turkey, which offers continuous customer support, Markafoni further incorporated online live chat application to the VIP customer support service which currently accommodate 7/24 telephone and online customer services. Furthermore, aiming to implement smooth and swift product return operations for the customers experiencing problems after purchasing the product, Markafoni accepts product returns from its customers within 30 days without charging any further fee. Upon taking delivery of the return cargo, Markafoni sends an information e-mail to the customer and return on POS payments are notified to the customer on the same day via SMS and e-mail. During the entire return process, the customers are constantly notified and keep informed about all stages of the process.

There is a private program entitled Markafoni Black available for Markafoni's frequently shopping members. Members of Markafoni Black program earn TL 20 instead of TL 10 from first shopping activity of every friend invited to Markafoni and enjoy free cargo services for all shopping activities. Members of Markafoni Black program further enjoy private services at the call center and might receive private style consultancy services at the private invitations and organizations organized specifically for such members.

Markafoni is also characterized as the first private shopping club engaged with smart cart application. By virtue of the smart cart application, which is valid for every campaign and product, members of Markafoni are capable of combining the products they wish to purchase from different campaigns within a single cart. This application significantly reduces the cargo costs of the members.

Being one of the limited e-commerce sites in Turkey holding Green Browser, which is solely granted to very secure e-commerce sites as a result of very strict audits, Markafoni provides shopping opportunities with maximum security for its members. Green browser application generally used at the Banking system in Turkey is only available at several e-commerce sites as well as Markafoni.

\subsection{Markafoni's Communication Strategies}

Markafoni realized a mass communication campaign in September 2011 contemplating the necessity of embracing a sentimental field in order to discriminate itself and create loyalty. With such campaign, Markafoni has become the first Turkish private shopping club, which realized 360 degrees mass communication campaign. Under the scope of this mass communication campaign, an advertisement film with the theme "Markafonik Love" was shot based on the notion that there are some common grounds between shopping from Markafoni and falling in love, such as curiosity, excitement, jealousy, expectation, and happy ending. The target audience is reached via television as well as through different channels including outdoor bulletins, press and internet. By virtue of such campaign, the brand awareness is enhanced not only in major cities but also in Anatolia. Taking cognizance of continuity in communication, Markafoni shall continue to remark "every shopping is falling in love" in this year through its novel communication campaign. Markafoni reaches to large masses through television commercial film, press releases, internet and radio jingles broadcasted under the scope of such new communication campaign. 
Social media applications of Markafoni are implemented through active availability in social sharing and video sites such as Facebook, Twitter, Pinterest, YouTube, Dailymotion, Vimeo and izlesene.com. Currently, there are more than 1 million followers on Facebook page of Markafoni, which never cuts off communication with its users and distributes awards through various contests. The number of followers on Twitter, on the other hand, is more than 40 thousand. The activities of Markafoni on Facebook have entered amongst global case studies of Facebook and Markafoni has become the first Turkish brand present in such global case studies. Moreover, being the first Turkish brand that actively uses Pinterest, the newly emerging star of the social media, Markafoni offers visuals from style and fashion world to its followers by means of Pinterest. The campaigns entitled "Show your Passion" and "My Love" organized by Markafoni on Twitter during the recent months not only attracted significant interest from fashion lovers but also created tremendous impression on the social media. Table 3 indicates the competitive analysis of Markafoni among its rivals.

Table 3. Competitive Analysis of Markafoni

\begin{tabular}{|c|c|}
\hline Facilities & Competitive Advantages \\
\hline being first in sector & $\begin{array}{c}\text { has large reputation and brand } \\
\text { awareness }\end{array}$ \\
\hline leading firm & others follow it \\
\hline have most member & it has the biggest pie of revenue \\
\hline strong after sale support & $\begin{array}{c}\text { creates customer loyalty and } \\
\text { engagement }\end{array}$ \\
\hline smart card & $\begin{array}{c}\text { enables to put all items from } \\
\text { different campaigns into one basket, } \\
\text { so customers pay only one parcel } \\
\text { fee }\end{array}$ \\
\hline $\begin{array}{c}\text { investing new emerging } \\
\text { markets like Ukraine }\end{array}$ & $\begin{array}{c}\text { increases revenue and profit and } \\
\text { takes the advantage of being first }\end{array}$ \\
\hline
\end{tabular}

\subsection{Year 2014 Business Plans of Markafoni}

Markafoni and its affiliates demonstrated 700 percent growth in year 2010 and 300 percent growth in year 2011. Markafoni and its affiliates experience very dynamic times also in year 2012. enmoda.com joined amongst the affiliates of Markafoni after acquisition of majority shares of enmoda.com, Turkey's online fashion center, and Markafoni established partnership with Doğuş Group. The impact of the acquisition of almost 70 percent of the shares of Markafoni by MIH_Allegro, an affiliate of Naspers, the multimedia giant of the world, which occurred in July 2011, still persists in year 2012. Taking firm steps towards becoming a global e-commerce brand, Markafoni is active in total of 8 countries abroad, particularly in Poland and Ukraine. For year 2014, Markafoni aims a growth rate much higher than the growth rate of e-commerce market in Turkey and endeavors to maintain such growth rate also in the hearth of its customers.

\section{Conclusion}

Nowadays, due to the increasingly competitive environment and changing consumer structures, most of companies carry their business to the electronic environment in order to reach a wide range of customers at less cost. E-retailing which is the basic element of this approach, is one of the most demanding e- business model in e-commerce system.

E-retails are operating in the electronic environment in different ways. Some of them are brokerage firms and direct selling firms and the rest is online e-retailing-merchandising firms. E- retailing-merchandising firms can differ in various structures in Turkey. There are some firms, which enable a virtual market place or providing niche services for consumers or there are some click and bricks, opportunity sites and private shopping clubs in online trading. On that point, private shopping clubs are new and very trendy e-retailing business model that operates very distinct logic from other e-commerce sites. These shopping clubs are closed systems that sell limited number of certain brands (Product groups could be from clothing, home furniture, personal care, restaurant, airplane, travel services etc...) online at discounts of up to $70 \%$ to its member customers. Private shopping clubs are famous around the world and Turkey as well. The reason of this popularity is based on the logic behind the system. These private shopping sites are exclusive and compelling high discounts to its members in a limited time. Most of sales events start at the same time and these events become a daily routine for site members as doing their breakfast in the morning.

This new concept of e-commerce for Turkey is Markafoni. Markafoni is the private shopping club, introducing the private shopping concept to Turkey in $2008.70 \%$ of the shares of Markafoni are held by MIH-Allegro, which is affiliated to Naspers, a worldwide known multimedia giant active in 129 countries.

The most important indicator of Markafoni's growing success could be explained by the amount of people they reach. Markafoni is visited 22 million times on monthly basis and the total number of individual visitors of Markafoni is reported to be 10 million individuals. More than 500 campaigns are organized in its website on monthly basis and 700 thousand products are sold on average.

Markafoni is taking rapid steps towards becoming a global brand with its creative marketing strategies and effective policies in the way through creating customer value. Markafoni is one of the best case of Turkey for Private shopping clubs as a new trend in e-retailing.

\section{REFERENCES}

[1] Yannopoulos, Peter, Impact of the Internet on Marketing Strategy Formulation, International Journal of Business and Social Science Vol. 2 No. 18; October 2011. 
[2] Jantarajaturapath, Palan\&Ussahawanitchkit, Phapruke, Ecommerce competencies and success of Thai e-commerce firms: A mediating of multichannel retailing advantage, Journal of Academy of Business and Economics, Volume 9, Number 3, 2009.

[3] Quelch, John \&Loisa Klein, The Internet and International Marketing, Sloan Management Review Spring, 60-75, 1996.

[4] Zhu, Kevin and Kraemer, Kenneth L., E-commerce Metrics for Net-enhanced Organizations: Assessing the Value e-commerce to firm performance in the manufacturing sector, Information Systems Research, Vol.13, 275-295, 2002.

[5] Agarwal, Ritu\&Venkatesh, Viswanath, "Assessing a Firm's Web Presence: A Heuristic EvaluationProcedure for the Measurement of Usability", Information Systems Research, Vol.13, 168-186.,2002.

[6] Online available: J.P Morgan 2011, The Global e-commerce Report, http://techcrunch.com/2011/01/03/j-p-morgan-global-e-com merce-revenue-to-grow-by-19-percent-in-2011-to-680b/06.0 8.2012

[7] Awais, Muhammed\&Samin, Tanzila, Advanced SWOT Analysis of E-Commerce, International Journal of Computer Science Issues, Vol. 9, Issue 2, No 2, March 2012

[8] Chang, Kuo-Chung, Joyce, Jackson \&Varun, Grover, E-commerce and Corporate Strategy: An Executive Perspective", Information \& Management, Vol.40, 663-675, 2003.

[9] Chen, Deng-Neng, Jeng, B., Lee, Wei-Po \& Chuang, Cheng-Hung, An Agent-based Model for Consumer-to-Business Electronic Commerce, Expert Systems with Applications, Vol.34, 469-481,2008

[10] Vaithianathan, Sridhar, A review of e-commerce literature on India and research agenda for the future, Electron Commer Res, 10: 83-97 DOI 10.1007/s10660-010-9046-0, 2010

[11] Jennex, Murray E., Amoroso, Don \&Adelakun, Olayele, E-Commerce Infrastructure Success Factors for small Companies in Development Economics, Electronic Commerce Research, Vol.4, 263- 286, 2004.

[12] Harris, L. and Dennis, C.E. Marketing the e-Business, London: Routledge, 2002.

[13] Dennis C. \&Fenech D.\&Merlieres BE- retailing, Free Press, Routledge, 2004.

[14] Online available: http://www.internetretailer.com/trends/e-retailers

[15] Online available: http://management.fortune.cnn.com/2012/0 4/11/avon-andrea-jung-downfall)
[16] Kotler P.\& Armstrong G., Principles of Marketing, 13 th.edition, Pearson, 2010

[17] Online available: Deliotte,2012, The Report of European e-Retailing Index http://www.deloitte.com/view/en_TR/tr/insights/deloitterese arch/ee29709d2c648310VgnVCM̄̄1000001956f00aRCRD.ht $\mathrm{m}$

[18] Online available: http://www.eticad.org.tr/bilgi-merkezi/sektorel-bilgiler/turki ye-genel-internet-verileri/

[19] Online available http://blog.euromonitor.com/2012/08/turkeys-e-commerce-s ector-boosted-by-economic-growth-and-young-populace.htm 1

[20] Online available: BKM's Report, The transaction of E commerce transactions with credit cards, http://www.bkm.com.tr/istatistik/sanal_pos_ile_yapilan_etic aret_islemleri.asp

[21] Online available: Tuik, 2012, The report of Internet technologies Household Survey of TUIK, 2012, http://www.tuik.gov.tr/PreHaberBultenleri.do?id=10880

[22] Online available:

http://interneticaret.blogspot.com/2010/02/turkiye-e-ticaret-i s-modelleri.html

[23] Online available: Deloitte,2011, The Report of Annual Turkish Mergers\& Acquisition Review, http://www.deloitte.com/view/en_TR/tr/insights/deloitterese arch/ee29709d2c648310VgnVCM̄M1000001956f00aRCRD.ht $\mathrm{m}$

[24] Online available: Marcus Stephanie, http://mashable.com/20 10/10/31/private-sales-success/

[25] Online available: http://pressroom.venteprivee.com/sitecore/ content/PR/PressReleases/2012/2011_results.aspx

[26] Online available: http://www.dailydealmedia.com/556the-gil t-groupe-may-approach-1-billion-in-revenues-in-2012-conte mplates-ipo

[27] Online available: http://socialcommercetoday.com/private-sh opping-clubs-critical-success-factors

[28] Online available:http://www.onedergi.com/2010/11/limango -turkiye-ceosu-gulfem-toygar-limangoyu-anlatti

[29] Online available: http://www.trendyol.com/hakkimizda.html

[30] Online available: http://www.ekonomihatti.com/e-ticaretin-onculeri-milyonlar a-ulasti.html

[31] Online available:http://www.markafoni.com 